\title{
LIMING AND FERTILIZATION TO RESTORE DEGRADED Brachiaria decumbens PASTURES GROWN ON AN ENTISOL
}

\author{
Patrícia Perondi Anchão Oliveira1,5; Antonio Enedi Boaretto2; Paulo Cesar Ocheuze Trivelin ${ }^{1 *}$; \\ Wladecir Salles de Oliveira ${ }^{3,5}$; Moacyr Corsi $^{4}$ \\ ${ }^{1}$ Lab. de Isótopos Estáveis - USP/CENA. \\ ${ }^{2}$ Lab. de Nutrição Mineral de Plantas - USP/CENA, C.P. 96 - CEP: 13400-970 - Piracicaba, SP. \\ ${ }^{3}$ Lab. de Biologia Molecular e Celular - USP/CENA. \\ ${ }^{4}$ Depto. de Zootecnia - USP/ESALQ, C.P. 09 - CEP: 13418-900 - Piracicaba, SP. \\ ${ }^{5}$ FAPESP Fellow. \\ ${ }^{*}$ Corresponding author <pcotrive@cena.usp.br>
}

\begin{abstract}
The reconstitution of soil fertility is essential in the process of pasture restoring, liming being the first action to be taken in this direction. The liming recommendation for pastures needs more technical information as the application method and rate. A field experiment was carried out to evaluate the liming and fertilization practices to restore a degraded Brachiaria decumbens pasture. The following factors were studied: liming method (incorporated in soil by disking or not); level of base saturation (40,50 or $80 \%$ ) and lime type $(55,70$ or 90 of ECC). Liming and fertilization (NPK and micronutrients) increased both the forage yield and its root system, these being more evident in the second year, even using the same rates of limeand fertilizer used during the first year. After two years the levels of base saturation aimed for the 0 to $0.20 \mathrm{~m}$ soil layer were not achieved, neither was the neutralization of the Al. The disking impaired the development of the root system of $B$. decumbens and promoted the decrease of soil organic matter. The lime with the lowest ECC increased root growth and led to higher concentrations of $\mathrm{Ca}$ and $\mathrm{Mg}$ in the soil. Studies in other conditions are necessary to define liming requirements in established and degraded pastures.
\end{abstract}

Key words: ECC, lime, restoration, base saturation, acid soils

\section{CALAGEM E ADUBAÇÃO NA RECUPERAÇÃO DE PASTAGEM DEGRADADA DE Brachiaria decumbens EM NEOSSOLO QUARTZARÊNICO}

\begin{abstract}
RESUMO: Na recuperação de pastagens é fundamental a reconstituição da fertilidade do solo, sendo a calagem a primeira ação nessa direção. A recomendação de calagem para pastagens necessita de maiores subsídios técnicos, como a forma de aplicação e a dose e o tipo de calcário a ser empregado. Um experimento de campo foi instalado para avaliar a calagem e a adubação como práticas para a recuperação de pastagens deBrachiaria decumbens degradadas. Os seguintes fatores foram estudados: a forma de aplicação do calcário (incorporado no solo com gradagem ou não incorporado), os níveis de saturação por bases de 40, 60 ou $80 \%$ e tipos de calcário (PRNT de 55, 70 ou 90). A calagem e a fertilização (NPK e micronutrientes) aumentaram as produções da forragem e do seu sistema radicular, sendo os efeitos mais acentuados no segundo ano, apesar do uso de mesmas doses de corretivos e fertilizantes do primeiro ano. Após dois anos não se conseguiu atingir os níveis de saturação por bases pretendidos na camada de $0-0,20 \mathrm{~m}$, bem como a neutralização do Al. A gradagem prejudicou o desenvolvimento do sistema radicular da forrageira e promoveu queda nos teores da matéria orgânica no solo. O calcário de PRNT mais baixo aumentou a produção de raízes e proporcionou as maiores concentrações de $\mathrm{Ca}$ e $\mathrm{Mg}$ no solo. Estudos em outras condições são necessários para se aprimorar a recomendação de calagem para pastagens estabelecidas e degradadas.

Palavras-chave: PRNT, calcário, restauração, saturação por bases, solos ácidos
\end{abstract}

\section{INTRODUCTION}

Degraded Brachiaria pastures are supposed to cover 30 million ha of Brazil's territory (Zimmer et al., 1994). Restoring those areas may become strategic, both, for the economical importance of the agro-systems, and for their preservation, since degradation is very associated to erosion, causing sediment deposition in rivers and lakes. Adequate physiological management of forages and soil fertility improvement are necessary practices to be performed to restore degraded pastures.
Liming and fertilization are important actions to improve soil fertility, although liming of pastures being a controversial issue and, therefore, additional research is needed to clarity some liming aspects on established pastures.

Werner et al. (1996) recommended a soil base saturation (BS) of $70 \%$ for planting or $60 \%$ for pasture maintenance, for Pennisetum purpureum, Panicum maximum, Cynodon dactylon, Digitaria decumbens, Hyparrhenia rufa and Chloris gayana pastures; $60 \%$ of BS for the formation period or $50 \%$ for the maintenance 
of Brachiaria brizantha, Andropogon gayanus e Cynodon plectostachyus pastures; and $40 \%$ of BS for the formation period or maintenance of Brachiaria decumbens, Brachiaria humidicola, Melinis minutiflora, Paspalum notatum and Setaria anceps pastures.

Maximum yield for Brachiaria brizantha and Panicum maximum, growing in greenhouse conditions, were obtained under soil BS of $43 \%$ and $47 \%$, respectively (Premazzi, 1991). In the first year after lime application, there was no effect on Panicum maximum 'Tobiatã' pasture yield, despite of the soil BS value of $31 \%$ and that lime amounts were applied in order to reach $60 \%$ or $80 \%$ (Luz et al., 1998), although these authors are not sure if the aimed BS levels were reached or not.

Effects of liming and fertilization of degraded pastures for restoration seem to be more evident when they are monitored for many years (Couto et al., 1985; Macedo, 1985; Sanzonowicz et al., 1987; Carvalho et al., 1992; Paulino et al., 1994). Macedo (1985) observed an increase from 14 to $38 \%$ in forage yield over a five year period, for Festuca pasture mixed with legumes, althrough liming was not effective in the first year. Sanzonowicz et al. (1987) observed an increase in Brachiaria decumbens forage yield after ten years of liming. Positive response of Brachiaria brizantha pasture was observed for lime rates until $2.0 \mathrm{Mg} \mathrm{ha}^{-1}$, as well increases of the effectiveness of phosphate fertilization (Paulino et al., 1994). Similar findings were obtained by Couto et al. (1985).

Disking for lime incorporation in soil cultivated with pastures is a controversial practice (Arruda et al., 1987; Soares Filho et al.; 1992 and Luz et al., 1998). A slight increase on forage yield $\left(130 \mathrm{~kg} \mathrm{ha}^{-1}\right)$ was observed when lime was incorporated into the soil of a degraded Panicum pasture by disking (Luz et al., 1998). On the other hand, disking decreased the dry aboveground matter of Brachiaria decumbens pasture (Soares Filho et al., 1992).

There are several reports in the literature showing that anions (especially chloride, sulfate and nitrate) are responsible for increasing $\mathrm{Ca}$ and $\mathrm{Mg}$ leaching (Lopes, 1984; Souza e Ritchey, 1986; Raij, 1991; Quaggio et al., 1982). Those anions may be supplied by fertilization, by organic matter decomposition, and by gypsum application (Raij, 1991). Lime incorporation showed, therefore, be avoided in established pastures.

In order to study liming effects on the restoration of degraded pastures, an experiment was carried out using an established Brachiaria decumbens pasture, growing on an Arenic soil. This experiment evaluated disking for lime incorporation in to the soil, and different amounts of dolomitic limestone, based on aimed values of BS and ECC.

\section{MATERIAL AND METHODS}

The degraded Brachiaria decumbens pasture was established on an Entisol of São Pedro, SP, Brazil $\left(47^{\circ} 56^{\prime} \mathrm{W}, 22^{\circ} 30^{\prime} \mathrm{S}\right)$. Soil chemical analyses are shown in Table 1. This study tested two methods of lime application: 1. on the surface and 2. on the surface disk incorporation to the $20 \mathrm{~cm}$ of soil depth; limestone with three effective calcium carbonate (ECC) levels: 55,70 and 90; and three aimed base saturation (BS) levels 40, 60 and $80 \%$. Two controls were used: both with neither fertilization nor liming, but one included disking. Lime rates and types, and aimed BS values are presented in Table 2. The experiment consisted of a factorial randomized block design, with four replications. Plots measured $10 \mathrm{~m}^{2}, 2 \mathrm{~m} \times 5 \mathrm{~m}$.

Dolomitic lime was applied twice: in June 1995 and in June 1996. Limestone incorporation down to the $0.20 \mathrm{~m}$ soil depth was made in October 1995, since it caused plant death and a delayed plant regrowth in first year after disking. The lime contained 24 and $16 \%$ of $\mathrm{CaO}$ and $\mathrm{MgO}$, respectively, with purity (percent $\mathrm{CaCO}_{3}$ equivalent) of $83 \%$. The ECC levels of 55,70 and $90^{3}$ were reached by mixing the lime from the same source but with distinct finenesses. Lime rates (Table 2) were calculated for the correction of the $0.20 \mathrm{~m}$ soil layer, reaching the aimed BS values, according to Raij (1991).

Cuts for pasture height homogenization was made in October 1995 and October 1996. In the same periods, the corrective fertilization was made with ordinary superphosphate (100 kg ha-1 of $\mathrm{P}_{2} \mathrm{O}_{5}$ ), potassium chloride (enough to raise the $\mathrm{K}$ level in the CEC from initial values to $5 \%)$ and micronutrients $\left(20,15\right.$ and $10 \mathrm{~kg} \mathrm{ha}^{-1}$ of borax, zinc sulfate and copper sulfate, respectively). In the second year, liming and fertilization were based on the results of the soil analyses for each treatment. After each cut, in the rainy season (November to March), maintenance fertilization was made by five split applications of $60,15 \mathrm{e}$ $60 \mathrm{~kg} \mathrm{ha}^{-1}$ of $\mathrm{N}, \mathrm{P}_{2} \mathrm{O}_{5}$ and $\mathrm{K}_{2} \mathrm{O}$, respectively. Corrective and maintenance fertilizations were made for high forage yield, following Corsi and Nussio (1994).

Botanical identification of plants mixed with $B$. decumbens was performed during the first year, and no more than $1 \%$ of the total biomass was Paspalum $s p$ and some broadleaf species.

Table 1 - Soil chemical analysis of the Typic Quartzipsament.

\begin{tabular}{|c|c|c|c|c|c|c|c|c|c|c|c|}
\hline Soil depth & & $\mathrm{MO}$ & $\mathrm{P}$ resin & $\mathrm{K}$ & $\mathrm{Ca}$ & $\mathrm{Mg}$ & $\mathrm{H}+\mathrm{Al}$ & $\mathrm{Al}$ & CTC & $\mathrm{V}$ & $\mathrm{m}$ \\
\hline $\mathrm{m}$ & $\mathrm{pH} \mathrm{CaCl}{ }_{2}$ & $\mathrm{~g} \mathrm{dm}^{-3}$ & $\mathrm{mg} \mathrm{dm}^{-3}$ & $-\cdots$ & -- & $\mathrm{mm}$ & $\mathrm{dm}^{-3}--$ & 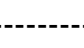 & $-\ldots$ & -- & ----- \\
\hline $0-0.20$ & 4.0 & 19 & 2.5 & 0.6 & 6.4 & 4.2 & 34.4 & 7.5 & 45.6 & 25 & 40 \\
\hline $0.10-0.30$ & 3.9 & 18 & 3.0 & 0.3 & 5.0 & 3.0 & 38.0 & 10.0 & 46.3 & 18 & 55 \\
\hline
\end{tabular}

Scientia Agricola, v.60, n.1, p.125-131, Jan./Mar. 2003 
Four randomized sub samples of forage $(0.3 \mathrm{~m}$ $x 0.6 \mathrm{~m}$ ) from each plot were harvested by hand. Six cuts during the agrostological year 1995/1996 and seven 1996/1997 were performed. Forage was cut made $0.15 \mathrm{~m}$ above ground level, each 35 or 60 days in summer or winter, respectively, starting in October 1995. Forage and root dry matter yield were evaluated for each cut. Root samples were collected with soil tubes. Roots were separated from soil by washing and collecting then in a $0.75 \mathrm{~mm}$ mesh sieve. Forage and root samples were dried at $65^{\circ} \mathrm{C}$ for $48 \mathrm{~h}$ to obtain dry matter.

In order to evaluate soil fertility, soil samples were collected at the beginning of the experiment, six months after liming and at the end of the growth period of each year, at depths of $0-0.05 \mathrm{~m}, 0.05-0.10 \mathrm{~m}$ and $0.10-0.30$ $\mathrm{m}$. Exchangeable cations and resin-exchangeable soil $P$ were determined, according to the methods described by Raij et al. (1987). The $\mathrm{pH}$ value was measured in $\mathrm{CaCl}_{2}$ $\left(0.01 \mathrm{~mol} \mathrm{~L}^{-1}\right)$.

Orthogonal contrasts were used to compare treatments and analysis of variance was applied for the factorial treatments, in order to evaluate treatment effects and interactions among them. Means were compared by the $\mathrm{F}$ test. A regression analysis was also implemented.

Table 2 - Dolomitc lime rates (24 and $16 \%$ of $\mathrm{CaO}$ and $\mathrm{MgO}$, respectively). $E C C=$ effective calcium carbonate; $\mathrm{BS}=$ base saturation.

\begin{tabular}{|c|c|c|c|c|}
\hline \multicolumn{3}{|c|}{ Treatments } & \multicolumn{2}{|c|}{ Dolomitc lime } \\
\hline Incorporation & ECC & BS aimed & 1995 & 1996 \\
\hline & & $\%$ & \multicolumn{2}{|c|}{------- Mg ha'-1 --.--- } \\
\hline Disking & 55 & 40 & 1.3 & 0.8 \\
\hline Disking & 55 & 60 & 2.9 & 2.3 \\
\hline Disking & 55 & 80 & 4.6 & 3.8 \\
\hline Surface & 55 & 40 & 1.3 & 0.6 \\
\hline Surface & 55 & 60 & 2.9 & 1.3 \\
\hline Surface & 55 & 80 & 4.6 & 3.5 \\
\hline Disking & 70 & 40 & 1.0 & 0.4 \\
\hline Disking & 70 & 60 & 2.3 & 1.3 \\
\hline Disking & 70 & 80 & 3.6 & 2.1 \\
\hline Surface & 70 & 40 & 1.0 & 0.2 \\
\hline Surface & 70 & 60 & 2.3 & 0.9 \\
\hline Surface & 70 & 80 & 3.6 & 2.3 \\
\hline Disking & 90 & 40 & 0.8 & 0.4 \\
\hline Disking & 90 & 60 & 1.8 & 1.2 \\
\hline Disking & 90 & 80 & 2.8 & 2.0 \\
\hline Surface & 90 & 40 & 0.8 & 0.3 \\
\hline Surface & 90 & 60 & 1.8 & 0.8 \\
\hline Surface & 90 & 80 & 2.8 & 2.0 \\
\hline Disking & Control & Control & 0 & 0 \\
\hline Surface & Control & Control & 0 & 0 \\
\hline
\end{tabular}

Scientia Agricola, v.60, n.1, p.125-131, Jan./Mar. 2003

\section{RESULTS AND DISCUSSION}

Soil chemical analysis results (surface soil layer of $0.20 \mathrm{~m}$ ) collected before applying treatments indicate low BS, high aluminum saturation, medium contents of $\mathrm{Ca}$ and $\mathrm{Mg}$ and low contents of $\mathrm{P}$ and $\mathrm{K}$, according Raij et al (1996). These results permit to foresee a response of the pasture to fertilization with $\mathrm{P}$ and $\mathrm{K}$, and possible response to $\mathrm{N}$ due to the low organic matter soil content. Liming for pasture of $B$. decumbens is recommended by Werner et al. (1996) when BS is lower than $40 \%$. The chosen experimental design did not permit to know if the pasture response was due to liming or fertilization, although all necessary conditions for liming response of pasture were present. The fertilization improved soil $\mathrm{K}$ and $P$ contents (from 0.6 and 2.5 to $2.6 \mathrm{mmol}_{\mathrm{c}} \mathrm{dm}^{-3}$ and $4.9 \mathrm{mg} \mathrm{dm}^{-3}$, respectively).

Forage dry matter yield was higher for all liming plus fertilization treatments in relation to control treatments. In the first year, the increase in forage dry matter due to both, liming and fertilization, were around $2 \mathrm{Mg} \mathrm{ha}^{-1}$ in first year and $4 \mathrm{Mg} \mathrm{ha}^{-1}$ in second year (Figure 1). Since weeds accounted for not more than 1\% of the total biomass, the floristic composition was determined only for the first year.

Despite the fact that the same fertilization and liming rates were used in the two years, the increase in forage yield was markedly higher in the second year. This may be due to the gradual soil fertility improvement (Corsi e Martha Júnior, 1997) and to the recovery of plant structures, since pasture restoring is positively related to plant shoot and root yield (Oliveira, 2001). Climatic conditions did not seem to affect pasture yield, since there was no significant variation over the experimental period.

Soares Filho et al. (1992) found that fertilization with macro and micronutrients to restore a degraded $B$. decumbens pasture promoted higher forage yield in second year $\left(13.1 \mathrm{Mg} \mathrm{ha}^{-1}\right)$ as related to the first year (3.8 $\mathrm{Mg} \mathrm{ha}^{-1}$ ), even with lower nitrogen fertilization (96 kg $\mathrm{ha}^{-1}$ ) as compared to the present experiment.

Comparisons among treatments with fertilization plus liming, indicated no effect on forage yield of Brachiaria decumbens, for different lime types (different ECC), lime amounts to obtain aimed BS values, or disking.

ECC is considered to be an adjustment coefficient (Raij, 1991), which minimizes the differences among the lime types for the same soil BS aimed level. Soil BS obtained (from 42 to $58 \%$ ) in the 0-0.05 m soil depth, may have supplied $\mathrm{Ca}$ and $\mathrm{Mg}$ to the forage during the pasture restoring process, which is in agreement with the findings of Werner et al. (1996) for established pastures of Brachiaria decumbens. As a matter of fact, even after two years of lime application, none of the aimed soil BS were reached (Figure 2). 
Contrarily to the results obtained by Luz et al. (1988) and Soares et al. (1992), disking did not affect forage yield, for treatments with and without liming. Soares et al. (1992) found that disking decreased forage yield in the second year for $B$. decumbens pasture in a restoring process.

Liming and fertilization caused an increase $(P<$ $0.05)$ in $B$. decumbens root dry matter in relation to controls for the $0-0.05 \mathrm{~m}$ and $0.05-0.10 \mathrm{~m}$ soil layers, during the second and first years (Figure 3 ). This might have been a consequence of decreasing the aluminum saturation and increasing macro and micronutrient soil availabilities in the layer $0.10 \mathrm{~m}$, due to liming and fertilization. In the second year, an increase of $100 \%$ in root mass was observed for all treatments, in relation to the first year.

Disking for lime incorporation should be avoided since the root dry matter decreased in soil layers up to $0.30 \mathrm{~m}$ (Figure 4), probably due to root death and slow regrowth of $B$. decumbens. Soares Filho et al. (1992) also observed decreases in root production after disking in a pasture restoring process, even when fertilization was made.

Root mass was found to be affected $(P<0.05)$ only by lime ECC for the second year, in the $0-0.05 \mathrm{~m}$ soil layer. Lime ECC of 55 resulted in a higher root mass (7.1 $\mathrm{Mg} \mathrm{ha}^{-1}$ ) compared to 70 and 90 lime ECC values (5.9 and $5.5 \mathrm{Mg} \mathrm{ha}^{-1}$, respectively). $\mathrm{Mg}$ is supposed to affect root growth more than $\mathrm{Ca}$, since the $\mathrm{Ca}$ content was high (> $7 \mathrm{mmo}_{\mathrm{dm}}^{-3}$, according to Raij et al., 1996) for all the treatments in the $0-0.10 \mathrm{~m}$ soil layer (Figure 5 and 6). The content of $\mathrm{Mg}$ was high (> $8 \mathrm{mmol}_{\mathrm{c}} \mathrm{dm}^{-3}$, according Raij et al., 1996) in $0.05 \mathrm{~m}$ soil layer, only for lime ECC of $55\left(9.1 \mathrm{mmol}_{\mathrm{c}} \mathrm{dm}^{-3}\right)$, while for the lime ECC 70 and $90, \mathrm{Mg}$ contents were medium, 6.2 and $7.4 \mathrm{mmol}$ $\mathrm{dm}^{-3}$, respectively (5 - $8 \mathrm{mmol}_{\mathrm{c}} \mathrm{dm}^{-3}$, according Raij et al., 1996), for the same soil layer (Figure 7). Sanzonowicz et al. (1987) observed a positive effect of Mg fertilization on forage yield.

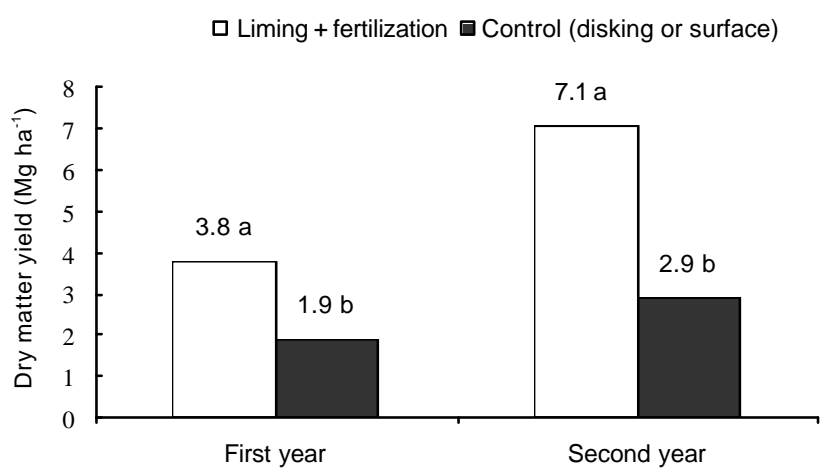

Figure 1 - Dry matter yield of the Brachiaria decumbens as a function of liming associated to fertilization.

*Means followed by different letter, within a experimental year, are different by $\mathrm{F}$ test $(P \leq 0.01)$;

${ }^{* *}$ CV de 29 and $16 \%$, for first year and second year, respectively.
The two-year period was not long enough to the raise soil BS to the aimed levels (Table 2), which is in agreement with the findings of Caires \& Fonseca (2000), who investigated the effect of surface liming application in no-tillage cropping, and by Guimarães (2000), who worked on Brachiaria and Echinochloa pastures. The deeper the soil layer and the higher the proposed BS level, the most difficult it was to reach the preset soil BS values (Figure 2). The aimed BS of $40 \%$ was only successfully reached for soil layers down to the $0.05 \mathrm{~m}$ of depth. The BS remained quite low at the $0.10-0.30 \mathrm{~m}$ depth, ranging from 21 to $25 \%$ (Figure 2), just a little higher than the $18 \%$ observed before the beginning of the experiment (Table 1).

Four hypotheses can be proposed to explain the results presented above: 1 . the calculation of lime rates based on BS values to be reached in a soil with an established B. decumbens pasture (Raij et al., 1996) may underestimate the lime amount to be applied; 2 . part of the lime amount applied did not react with the soil, as explained by Caires \& Fonseca (2000); 3. the harvested forage may have removed some $\mathrm{Ca}$ and $\mathrm{Mg}$; and 4 . some of the applied $\mathrm{Ca}$ and $\mathrm{Mg}$ leached from the surface soil layer. Quaggio et al. (1982) observed annual leaching losses of $20 \%$ of $\mathrm{Ca}$ and $\mathrm{Mg}$ applied when lime was incorporated in a soil layer of $0.20 \mathrm{~m}$ depth, in a "Cerrado" soil, Hapludox.

In relation to $\mathrm{Ca}$ and $\mathrm{Mg}$ removals by the forage in the first year, they can be estimated around 15 and $10 \mathrm{~kg} \mathrm{ha}^{-1}$, respectively, and around 28 and $19 \mathrm{~kg} \mathrm{ha}^{-1}$ in the second year. Those values were calculated based on the forage yield of treatments with liming and fertilization (Figure 1), and on mean $\mathrm{Ca}\left(4 \mathrm{~g} \mathrm{~kg}^{-1}\right)$ and $\mathrm{Mg}(2.75$ $\mathrm{g} \mathrm{kg}^{-1}$ ) contents in the Brachiaria brizantha dry matter (Werner et al., 1996). These amounts are quite lower than those applied (188 and $70 \mathrm{~kg} \mathrm{ha}^{-1}$ of $\mathrm{Ca}$ and $\mathrm{Mg}$, respectively, corresponding to the lowest lime rates, 1100 $\mathrm{kg} \mathrm{ha}^{-1}$ over the two years), but they account for $22 \%$ of $\mathrm{Ca}$ and $41 \%$ of $\mathrm{Mg}$ applied over the two years.

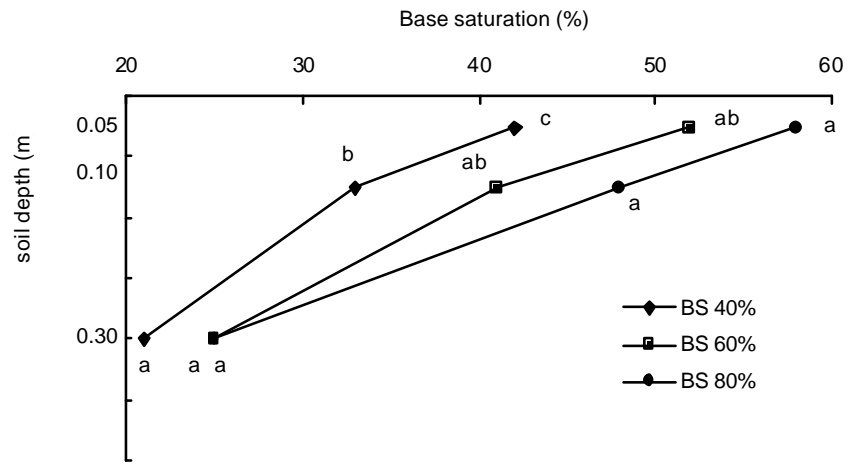

Figure 2 - Soil base saturation in the second year at different soil depths.

* Means, within soil depth, followed different letters are by Tukey test $(P=0.05)$.

${ }^{* *} \mathrm{CV}$ of 28,33 and $43 \%$, for soil depth $0-0.05,0.05-0.10$ and 0.10 $0.30 \mathrm{~m}$, respectively. 
a Liming + Fertilization $\quad$ a Control

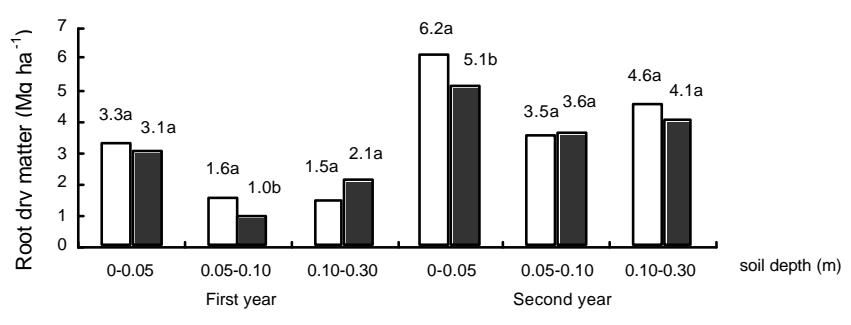

Figure 3 - Brachiaria decumbens root distribution in the soil. *Means, within a year and soil depth, followed by different letters are different by $\mathrm{F}$ test $(P \leq 0.05)$;

${ }^{\star *} \mathrm{CV}$ between 26 and $39 \%$, depending to year and depth.

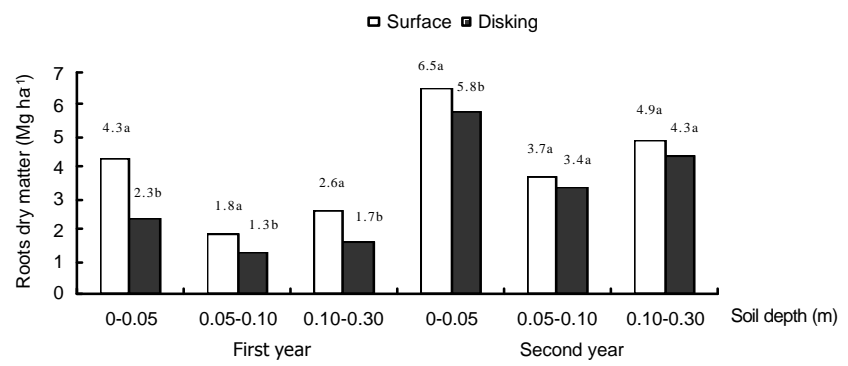

Figure 4 - Brachiaria decumbens roots as a function of lime application methods.

* Mean, within year and soil depth, followed by different letters are different by $\mathrm{F}$ test $(P=0.05$ and $P=0.01$, in the first and second year respectively)

${ }^{* *} \mathrm{CV}$ ranged from 20 to $38 \%$ depending on year and depth.

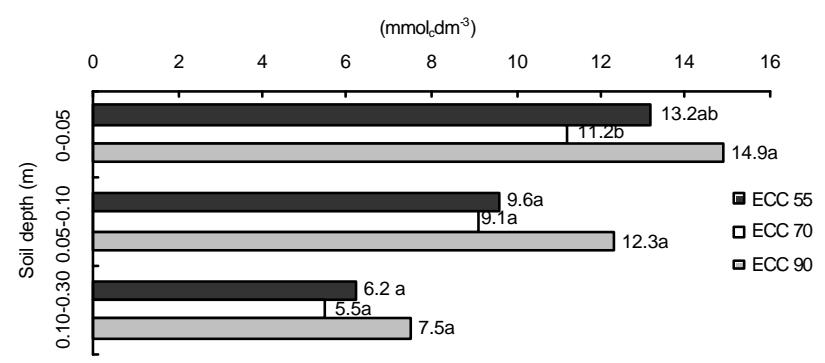

Figure 5 - Calcium soil content at the end of experiment as a function of the lime Effective calcium carbonate.

*Means, within a soil depth, followed by different letters are different by Tukey test $(P \leq 0.05)$.

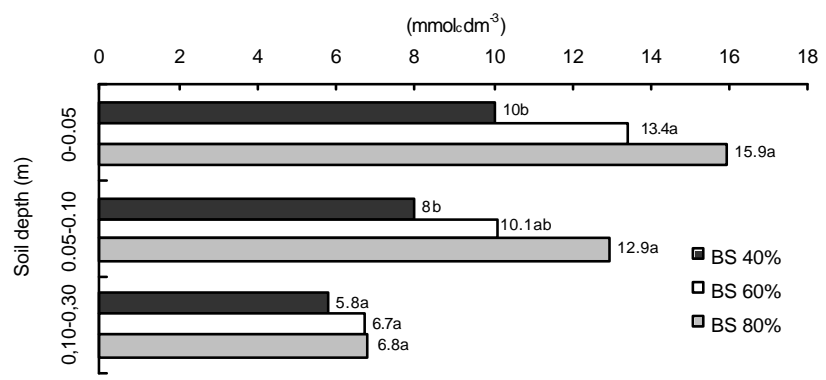

Figure 6 - Calcium soil content as a function of the soil Base Saturation at the end of experiment (1997).

* Means, within a soil depth, followed by different letters are different by Tukey test $(P \leq 0.05)$.

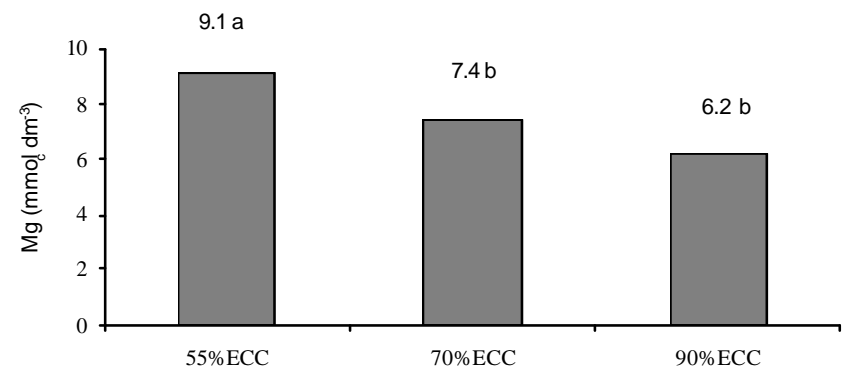

Figure 7 - Magnesium soil content as a function of Effective calcium carbonate (depth $0-0.05 \mathrm{~m}$ ) at the end of experiment (1997).

* Means, within a soil depth, followed by different letters are different by Tukey test $(P \leq 0.05)$.

With reference to lime reaction in the soil, the data of Allen \& Hossner (1991) indicated the presence of residual lime in soils of several sites in Texas (USA) after 10 years of liming. Residual lime content in the soil profile was calculated by determining the calcium carbonate equivalent and the residual lime itself, as well as calcite and dolomite contents in the residual lime through X-ray diffraction. Residual lime was found down to a $0.08 \mathrm{~m}$ soil depth, for a $5.5 \mathrm{pH}$ in the topsoil. When soil $\mathrm{pH}$ was lower than 5.5 , like in the present experiment, all lime reacted, resulting in no residual lime, even in soil surface.

Liming increases soil $\mathrm{BS}$ and $\mathrm{pH}$ values and decreases Al saturation (Camargo et al., 1997), as indicated by the data obtained at the end of the experiment (Figures 8 and 9).

Liming increased CEC for the $0.05 \mathrm{~m}$ soil layer, but no effect was observed in deeper layers. The highest CEC value was observed for the aimed soil BS of $60 \%$ applying a lime ECC of 70 (Figure 10).

Soil organic matter contents decreased due to disking for lime incorporation, which may have caused the decomposition of organic matter (Figure 11), although the two years of Brachiaria decumbens pasture had the initial organic matter soil content increased.

Lime application on soil surface, with no incorporation, allows pastures to become a permanent cover cropping system, which is less vulnerable to erosion and nutrient losses, maintaining or even enhancing organic matter contents.

The low BS observed for the $0.10-0.30 \mathrm{~m}$ soil layer (Figure 2) associated to the low $\mathrm{Ca}$ and $\mathrm{Mg}$ contents (Figures 6 and 7), and to the high Al contents (Figure 9), may indicate that the organic matter (Miyazawa et al., 2000) and/or associated anions (Souza \& Ritchey, 1986), supplied by dead forage remaining on the soil surface and by the high rates of fertilizers (ordinary superphosphate and potassium chloride), were not enough to reduce soil acidity and Al contents deeper than $0.10 \mathrm{~m}$. 


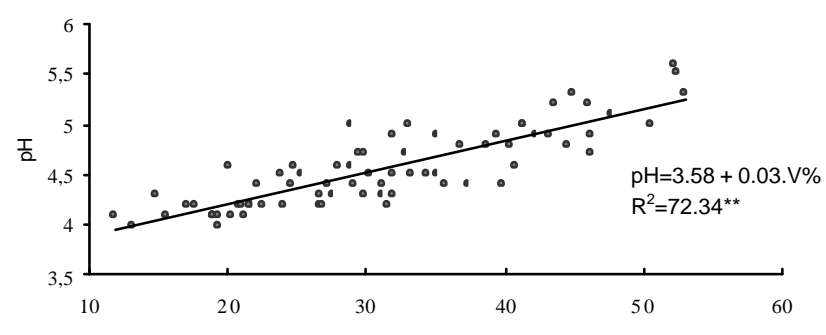

$\mathrm{BSI}$

Figure 8 - Values of Base saturation obtained at the end of the experiment in relation to soil $\mathrm{pH}$, for the depth $0-0.30 \mathrm{~m}$.

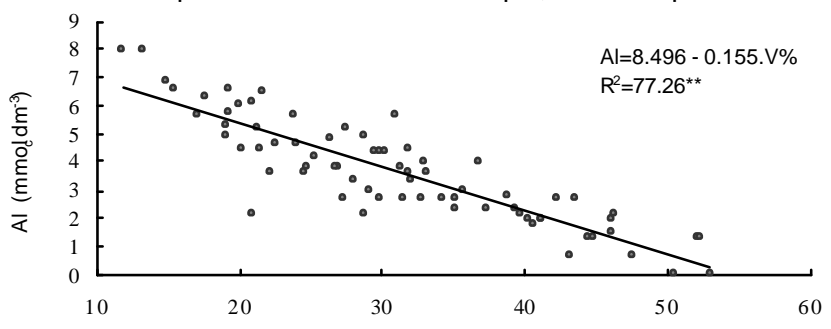

BS

Figure 9 - Values of Base saturation obtained at the end of the experiment in relation to $\mathrm{Al}$ soil content, for the depth 0 $0.30 \mathrm{~m}$.

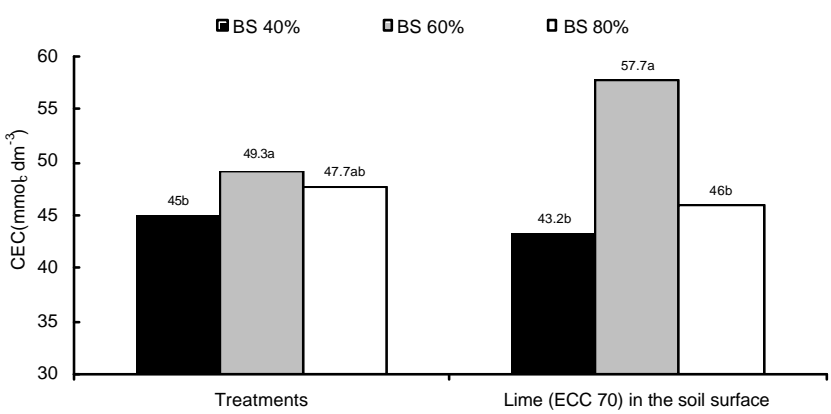

Figure 10 - CEC values as a function of Base saturation, for the soil depth 0-0.05 m, at the end of the experiment (1997). *Means, within each collective column, followed by different letter are different by Tukey test $(P \leq 0.05)$.

$$
\text { - } \text { Surface Disking }
$$

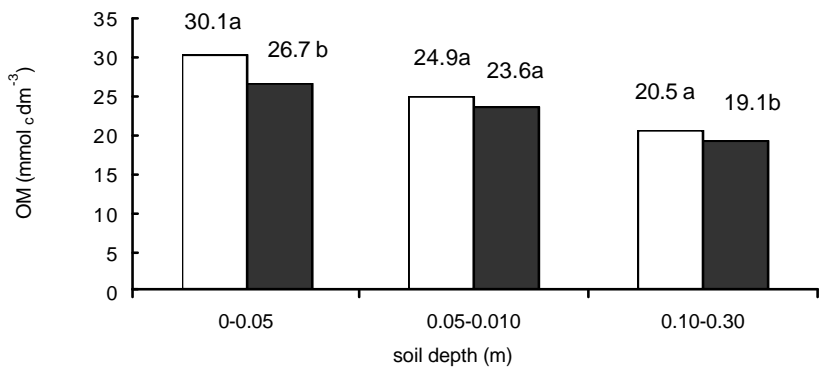

Figure 11 - Lime application methods in relation to soil organic matter content.

*Means, within a soil depth, followed by different letters are different by Tukey test $(P \leq 0.05)$.

\section{CONCLUSIONS}

Liming and fertilization (N-P-K and micronutrients) prove an increase in forage and root yield, mainly in the second year after starting pasture rehabilitation, and recover Brachiaria decumbens degraded pastures.
For forage yield of Brachiaria decumbens the best treatment was no incorporation of lime by disking, which was harmful to root growth and decreased organic matter content of the soil layer down to the $0.30 \mathrm{~m}$ depth, over two years after starting pasture rehabilitation.

The preset BS values were not reached, even after two years of liming.

ECC Lime of 55, within a given BS, results in increases of root yield and magnesium soil content.

\section{ACKNOWLEDGMENT}

To Empresa Brasileira de Calcário Ltda., which supported financially this research.

\section{REFERENCES}

ALLEN, E.R.; HOSSNER, L.R. Factors affecting the accumulation of surfaceapplied agricultural limestone in permanent pastures. Soil Science, v.151, p.240-248, 1991

ARRUDA, N.G.; CANTARUTTI, R.B.; MOREIRA, E.M. Tratamentos físicomecânicos e fertilização na recuperação de pastagens de Brachiaria decumbens em solos de Tabuleiro. Pasturas Tropicales, v.9, p.36-39, 1987.

CAIRES, E.F.; FONSECA, A.F.da. Absorção de nutrientes pela soja cultivada no sistema de plantio direto em função da calagem na superfície. Bragantia, v.59, p.213-220, 2000.

CAMARGO, O.A.; CASTRO, O.M.; VIEIRA, S.R.; QUAGGIO, J.A. Alteração de atributos químicos do horizonte superficial de um latossolo e um podzólico com a calagem. Scientia Agricola, v.54, p.1-8, 1997.

CARVALHO, M.M.; MARTINS, C.E.; SIQUEIRA, C.; SARAIVA, O.F. Crescimento de uma espécie de braquiária, na presença da calagem em cobertura e de doses de nitrogênio. Revista Brasileira da Ciência do Solo, v.16, p.69-74, 1992.

CORSI, M.; NUSSIO, L.G. Manejo do capim elefante: correção e adubação do solo em sistemas intensivos de pastejo rotacionado. In: SIMPÓSIO SOBRE MANEJO DA PASTAGEM, 14., Piracicaba, 1997. Anais. Piracicaba: FEALQ, 1997. p.161-193.

CORSI, M.; MARTHA JÚNIOR. Manutenção da fertilidade do solo em sistemas intensivos de pastejo rotacionado In: SIMPÓSIO SOBRE MANEJO DA PASTAGEM, 14., Piracicaba, 1997. Anais. Piracicaba: FEALQ, 1997. p.161-193

COUTO, W.; LEITE, G.C.; KORNELIUS, E. The residual effect of $P$ and lime on the performance of four tropical grasses in a high P-fixing oxisol. Agronomy Journal, v.77, p.539-542, 1985.

GUIMARÃES, G.F.P.B. Avaliação de quatro forrageiras tropicais cultivada em dois solos da ilha de Marajó-PA submetidos a crescentes saturações por bases. 2000. 197p. Dissertação (Mestrado) - Escola Superior de Agricultura "Luiz de Queiroz", Universidade de São Paulo.

LOPES, A.S. Solos sob "Cerrado". Piracicaba: Associação Brasileira para Pesquisa da Potassa e do Fosfato, 1984. 162p.

LUZ, P.H. de C.; BRAGA, G.J.; HERLING, V.R.; LIMA, C.G.L. Efeitos de tipos, doses e incorporação de calcário sobre as características agronômicas do Panicum maximum Jacq. cv. Tobiatã. In: REUNIÃO DA SOCIEDADE BRASILEIRA DE ZOOTECNIA, 35., Botucatu, 1998. Anais. Brasília: SBZ, 1998. p.248-250

MACEDO, W. Efeito de fontes e níveis de fósforo e calcário na adubação de forrageiras em solos do RGS. Pesquisa Agropecuária Brasileira, v.20, p.643-657, 1985

OLIVEIRA, P.P.A. Manejo da calagem e da fertilização nitrogenada na recuperação de pastagens degradadas de Brachiaria sp. em solos arenosos. 2001. 110 p. Tese (Doutorado) - Centro de Energia Nuclear na Agricultura, Universidade de São Paulo.

PAULINO, V.T.; COSTA, N. de L.; CARDELLI, M.A.; SCHAMMAS, E.A FERRARI Jr., E. Resposta de Brachiaria brizantha cv. Marandu a calagem e a fertilização fosfatada em um solo ácido. Pasturas Tropicales, v.16, p.34-40, 1994.

QUAGGIO, J.A.; MASCARENHAS, H.A.A.; BATAGLIA, O.C. Resposta da soja à aplicação de doses crescentes de calcário em latossolo roxo distrófico de cerrado. II- Efeito residual. Revista Brasileira da Ciência do Solo, v.6, p.113-118, 1992

PREMAZZI, L.M. Saturação por bases como critério para recomendação de calagem em cinco forrageiras tropicais. Piracicaba. 1991. 215p. Dissertação (Mestrado) - Escola Superior de Agricultura "Luiz de Queiroz", Universidade de São Paulo. 
RAIJ, B.; QUAGGIO, J. A.; CANTARELLA, H.; FERREIRA, M. E.; LOPES, A. S., BATAGLIA, O. C. Análise química do solo para fins de fertilidade. Campinas: Fundação Cargill, 1987. 170 p.

RAIJ, B. van; SILVA, N.M.; BATAGLIA, O.C.; QUAGGIO, J.A.; HIROCE, R. CANTARELLA, H.; BELLINAZZI Jr., R.; DECHEN, A.R.; TRANI, P.E. Recomendação de adubação e calagem para o Estado de São Paulo. Piracicaba: IAC, 1996. 105p.

RAIJ, B. van. Fertilidade do solo e adubação. Piracicaba: Agronômica Ceres; Associação Brasileira para Pesquisa da Potassa e do Fosfato, 1991. 343p. SANZONOWICZ, C.; LOBATO, E.; GOERDERT, W.J. Efeito residual da calagem e de fontes de fósforo numa pastagem estabelecida em solo de cerrado. Pesquisa Agropecuária Brasileira, v.22, p.233-243,1987.

SOARES FILHO, C.V.; MONTEIRO, F.A.; CORSI, M. Recuperação de pastagens degradadas: 1 . Efeito de diferentes tratamentos de fertilização e manejo. Pasturas Tropicales, v.14, p.2-6, 1992.

SOUZA, D.M.G. de; RITCHEY, K.D. Uso do gesso no solo de cerrado. In: SEMINÁRIO SOBRE O USO DO FOSFOGESSO NA AGRICULTURA, 1., Brasília, 1986. Anais. Brasília: EMBRAPA, DDT, 1986, p.119-145.
WERNER, J.C.; PAULINO, V.T.; CANTARELLA, H. Recomendação de adubação e calagem para forrageiras. In: RAIJ, B. van; SILVA, N.M.; BATAGLIA, O.C.; QUAGGIO, J.A.; HIROCE, R.; CANTARELLA, H.; BELLINAZZI, Jr., R.; DECHEN, A.R.; TRANI, P.E. Recomendacãa de adubação e calagem para o Estado de São Paulo. Campinas: Instituto Agronômico; Fundação IAC, 1996. p.263-271.

ZIMMER, A.H.; MACEDO, M.C.M.; BARCELLOS, A.deO.; KICHEL, A.N. Estabelecimento e recuperação de Brachiaria. In: SIMPÓSIO SOBRE MANEJO DA PASTAGEM, 11; Piracicaba, 1994. Anais. Piracicaba: FEALQ, 1994. p.153-208.

Received July 27, 2001 